\title{
ECZEMA COXSACKIUM: BENTUK ATIPIKAL HAND, FOOT, AND MOUTH DISEASE YANG DISEBABKAN OLEH COXSACKIEVIRUS A6
}

\author{
Astri Adelia, Windy Keumala Budianti, Evita Halim Effendi \\ Departemen Ilmu Kesehatan Kulit dan Kelamin \\ FK. Universitas Indonesia/RSUPN Dr. Cipto Mangunkusumo, Jakarta
}

\begin{abstract}
ABSTRAK
Eczema coxsackium merupakan spektrum hand, foot, and mouth disease (HFMD) yang disebabkan oleh coxsackievirus A6 (CVA6). Terdapat beberapa perbedaan pendapat di antara para klinisi mengenai definisi eczema coxsackium hingga saat ini, sehingga data epidemiologi penyakit sulit didapatkan. Telah dipublikasikan beberapa laporan mengenai kasus endemik HFMD yang disebabkan oleh CVA6 di Amerika Serikat (AS), New Zealand, beberapa negara di Eropa, dan Asia. Beberapa klinisi sering mengkaitkan penyakit ini dengan kejadian dermatitis atopik, meskipun hal tersebut belum ada penjelasannya. Patogenesis eczema coxsackium hingga saat ini belum diketahui dengan pasti. Manifestasi klinis yang timbul sangat bervariasi, lebih berat, dan luas, baik pada lesi kulit maupun mukosa dibandingkan dengan HFMD pada umumnya, sehingga lebih dikenal sebagai HFMD atipikal. Penegakan diagnosis eczema coxsackium tidak mudah karena dapat menyerupai penyakit lain dan harus dapat dibuktikan bahwa penyakit tersebut disebabkan oleh CVA6. Prinsip tatalaksana adalah rehidrasi. Prognosis eczema coxsackium adalah baik dan jarang menimbulkan komplikasi yang serius.
\end{abstract}

Kata kunci: eczema coxsackium, coxsackievirus A6, HFMD atipikal

\section{ECZEMA COXSACKIUM: ATYPICAL HAND, FOOT, AND MOUTH DISEASE CAUSED BY COXSACKIEVIRUS A6}

\begin{abstract}
Eczema coxsackium is a spectrum of hand, foot, and mouth disease (HFMD) caused by coxsackievirus A6 (CVA6). There are many differences opinion regarding the definition of eczema coxsackium, it makes the epidemiological data difficult to obtain. Several reports on endemic caseses of HFMD caused by CVA6 has been published in the United State of America (USA), New Zealand, some countries in Europe and Asia. Some experts often associate the disease with an incidence of atopic dermatitis, although there is no explanation on it. The pathogenesis of eczema coxsackium is not fully understood. Clinical manifestations occur more varied and severe, not only in the skin but also in the mucosal compared with general HFMD, so commonly known as atypical HFMD. The diagnosis of eczema coxsackium is not eassy established because of the clinical manifestations can mimic to other diseases and should be proven that the disease caused by CVA6. The principles treatment is rehydration. The prognosis of eczema coxsackium is good and it is rarely cause serious complications.
\end{abstract}

Keywords: eczema coxsackium, coxsackievirus A6, atypical HFMD

Korespondensi:

Jl. Diponegoro 71, Jakarta Pusat.

Telepon/Fax: 021-31935383

Email: astriadel@gmail.com 


\section{PENDAHULUAN}

Hand, foot, and mouth disease (HFMD) dipublikasikan pertama kali pada tahun 1957 oleh C.R. Robinson sebagai erupsi vesikular dan lesi di faring dengan demam yang mengenai anak pada musim panas di Toronto. ${ }^{1}$ HFMD kemudian dikenal sebagai penyakit infeksi yang ditandai dengan erupsi vesikular pada kulit dan mukosa oral, termasuk telapak tangan, telapak kaki, dan bokong. Penyakit ini paling sering disebabkan oleh coxsackievirus A16 (CVA16) dan enterovirus 71 (EV71), mengenai anak usia kurang dari lima tahun, ${ }^{2-4}$ atau disebut sebagai HFMD klasik.,3

HFMD, selain CVA16 dan EV71, juga dapat disebabkan oleh coxsackievirus serotipe lain, yaitu coxsackievirus A6 (CVA6). HFMD yang disebabkan oleh CVA6 (HFMD-CVA6) menimbulkan lesi kulit dan kelainan mukosa yang lebih luas dan bervariasi dibandingkan dengan HFMD klasik. ${ }^{1,2}$ Manifestasi yang tidak khas ini kemudian disebut sebagai HFMD atipik. ${ }^{1}$ Mathes dkk. ${ }^{1}$ menyebutkan beberapa manifestasi klinis HFMD atipik, salah satunya adalah eczema coxsackium. Tinjauan pustaka ini akan membahas mengenai eczema coxsackium, meliputi definisi, gambaran klinis, penegakkan diagnosis, dan tatalaksana. Manifestasi klinis HFMD atipikal bentuk lain tidak disertakan karena membutuhkan pembahasan lebih lanjut.

\section{DEFINISI}

Eczema coxsackium merupakan salah satu spektrum manifestasi klinis HFMD atipikal. Selain mengenai kulit dan mukosa pada area predileksi HFMD, lesi juga dapat timbul di bagian tubuh lain. Terdapat beberapa pendapat mengenai definisi eczema coxsackium, antara lain yang dikemukakan oleh Feder dkk., ${ }^{2}$ Johnson dkk., ${ }^{5}$ dan Horsten dkk., ${ }^{6}$ bahwa eczema coxsackium merupakan HFMD-CVA6 yang terjadi pada tempat predileksi dermatitis atopik (DA). Definisi tersebut didukung oleh Lott dkk., ${ }^{7}$ yang mendeskripsikan eczema coxsackium sebagai penyakit infeksi CVA6 dengan manifestasi klinis berupa erupsi papul eritematosa hingga vesikel pada tempat predileksi DA.

Studi oleh Hubiche dkk..$^{8}$ di tujuh klinik dermatologi anak, mempertegas hubungan DA dengan eczema coxsackium. Enam di antara 104 anak menunjukkan gambaran klinis sesuai dengan HFMD atipik, namun anak tersebut tidak dapat didiagnosis sebagai eczema coxsackium karena lesi yang timbul bukan di area DA dan tidak ada riwayat DA, walaupun terbukti disebabkan oleh CVA6.

Mathes dkk., ${ }^{1}$ menyebutkan empat gambaran klinis HFMD atipik yang berhubungan dengan CVA6, yaitu vesiculobullous and erosive eruption, eczema coxsackium, Gianoti Crosti-like eruption, serta petechial and purpuric rash. Pada studi ini, lesi kulit yang timbul bukan hanya pada area DA, namun juga pada area yang pernah mengalami trauma atau inflamasi sebelumnya. Inflamasi dapat disebabkan oleh luka bakar akibat matahari, dermatitis kontak, maupun infeksi. Berbeda dengan beberapa studi yang telah dikemukakan sebelumnya, Ventarola dkk., ${ }^{19}$ serta Harris dkk., ${ }^{10}$ justru menyebutkan bahwa tidak ada hubungan antara DA dengan eczema coxsackium.

\section{EPIDEMIOLOGI}

Beberapa publikasi berupa laporan kasus eczema coxsackium kini telah dapat ditemukan di Selandia Baru, Amerika Serikat (AS), Cuba, dan beberapa negara di benua Eropa dan Asia. Pada tahun 2010, di antara seluruh ksus HFMD yang dilaporkan terdapat kasus HFMDCVA6 sebesar 28,4\% terjadi di Perancis dan 47,3\% di China. Pada tahun 2011, insidens sebesar 90\% di Spanyol, 79,6\% di Jepang, dan 73,5\% di AS. Pada tahun 2013, di China dan Cuba sebesar 66,9\% dan 75\%. ${ }^{11}$

The Centers for Disease Control and Prevention, AS pada tahun 2012, menyebutkan bahwa 63\% pasien HFMD-CVA6 berusia di bawah dua tahun. ${ }^{12}$ Feder dkk., ${ }^{2}$ serta Yan dkk., ${ }^{13}$ juga melaporkan bahwa pasien lebih banyak terjadi pada anak di bawah usia tiga tahun. Selain anak HFMD-CVA6, juga dapat mengenai orang dewasa. Lott dkk. ${ }^{7}$ menyebutkan bahwa 24\% HFMD-CVA6 terjadi pada usia dewasa. Harris dkk. ${ }^{10}$ juga pernah melaporkan sebuah kasus HFMD-CVA6 tahun 2014 di Singapura pada seorang perempuan berusia 25 tahun. Terkait dengan usia, Chetrit dkk. ${ }^{14}$ menambahkan bahwa gejala yang timbul akan menjadi lebih parah jika mengenai orang dewasa.

Mathes dkk. ${ }^{1}$ melaporkan 53\% dari 80 kasus HFMDCVA6 lebih banyak terjadi pada perempuan dibandingkan dengan laki-laki. Sedangkan Yan dkk. ${ }^{13}$ menyebutkan laki-laki lebih banyak daripada perempuan dengan perbandingan 1,67:1. Berdasarkan warna kulit, terbanyak ditemukan pada orang kulit putih, yaitu 57\%, pada pasien anak dan dewasa. ${ }^{3}$

Insidens HFMD di divisi dermatologi anak dan umum Poliklinik Kulit dan Kelamin RSUPN Dr. Cipto Mangunkusumo Jakarta pada tahun 2014-2015 terdapat sebanyak empat kasus. Semua kasus yang dilaporkan terjadi pada anak, tiga kasus berusia kurang dari lima tahun dan satu kasus pada usia lima belas tahun. Hingga saat ini tidak ada laporan kasus eczema coxsackium yang pernah dilaporkan pada anak maupun dewasa. ${ }^{15,16}$

Lott dkk. ${ }^{7}$ melaporkan kasus HFMD-CVA6 yang terjadi di AS dipengaruhi oleh musim, paling banyak terjadi pada musim dingin dibandingkan dengan HFMD klasik yang justru lebih banyak terjadi pada musim panas dan musim gugur. ${ }^{1}$ Berbeda dengan laporan kasus sebelumnya, Yan dkk. ${ }^{13}$ menyebutkan bahwa HFMD-CVA6 paling banyak terjadi pada masa transisi musim dingin ke 
musim semi dan musim panas ke musim gugur. Mathes dkk. ${ }^{1}$ menyebutkan paling sering terjadi justru pada akhir musim semi dan awal musim panas.

\section{ETIOPATOGENESIS}

Coxsackievirus pertama kali ditemukan pada tahun 1948 oleh Dr. Gilbert Dalldorf, seorang ilmuwan yang bekerja di Departemen Kesehatan di Albany, New York. ${ }^{17}$ Virus ini termasuk dalam famili picornaviridae dan genus enterovirus. Termasuk di dalamnya adalah poliovirus dan echovirus. Coxsackievirus merupakan virus tidak berkapsul yang memiliki linear single-stranded ribonucleic acid (RNA). Coxsackievirus terbagi atas grup A dan B. Coxsackievirus grup A (CVA) memiliki 23 serotipe (1-22 dan 24) dan grup B (CVB) memiliki enam serotipe (1-6). ${ }^{18,19}$

CVA dapat menginfeksi kulit dan mukosa, yang merupakan penyebab herpangina, acute hemorrhagic disease (AHC), dan HFMD. Sedangkan CVB dapat menginfeksi jantung, pleura, pankreas, dan hati, serta menyebabkan pleurodynia, miokarditis, perikarditis, dan hepatitis. Kedua grup dapat menyebabkan demam dengan pola tidak spesifik, bercak kemerahan, penyakit saluran napas bagian atas, dan meningitis aseptik. ${ }^{20}$

Patogenesis eczema coxsackium dan kaitannya dengan CVA6 yang dapat menyebabkan manifestasi klinis HFMD atipik hingga saat ini belum diketahui. ${ }^{1}$ Coxsackievirus ditularkan secara fekal-oral dan oral-oral, atau melalui sekret pernapasan, cairan vesikel, bahkan melalui gigitan nyamuk. ${ }^{1,13,15}$ Virus akan masuk ke dalam tubuh dan menginfeksi laring serta saluran cerna kemudian menyebar ke kelenjar getah bening regional. Pada beberapa kasus langsung menyebar secara sistemik dan terjadi replikasi di sistem saraf pusat, kulit, atau jaringan tubuh lain (viremia primer). Setelah mengalami replikasi, virus menyebar kembali ke seluruh tubuh dan mengalami replikasi kembali di kulit, membran mukosa, sistem saraf pusat, jantung, dan beberapa organ lain (viremia sekunder). Virus ini sangat menular dalam minggu pertama setelah muncul gejala infeksi dan masih dapat ditemukan di feses hingga 4-8 minggu setelahnya. ${ }^{13}$

\section{MANIFESTASI KLINIS}

Gejala HFMD-CVA6 sangat bervariasi, dapat tidak bergejala, gejala ringan hingga berat. Hal tersebut dapat menyebabkan kesalahan diagnosis dengan penyakit inflamasi atau infeksi lainnya. ${ }^{6,15}$ Berbeda dengan HFMD klasik, menurut laporan kasus oleh Feder dkk. ${ }^{2}$ HFMDCVA6 menimbulkan gejala prodromal berupa demam yang lebih tinggi.

Masa inkubasi infeksi coxsackievirus cenderung singkat, antara 2-7 hari dengan lama sakit antara 3-35 hari. ${ }^{13,22}$ Pasien HFMD-CVA6 dapat menunjukkan gejala berupa nafsu makan menurun, produksi saliva me- ningkat, batuk atau pilek, dan gejala lain misalnya diare, muntah, dan nyeri kepala. ${ }^{22}$ Lesi kulit timbul 1-2 hari setelah demam, kemudian ulkus pada mukosa oral termasuk lidah. Lesi kulit juga dapat ditemukan pada telapak tangan, kaki, bokong, ${ }^{9}$ dan area genital..$^{22}$ Lesi erosi pada mukosa lebih jarang ditemukan pada HFMD-CVA6 dibandingkan dengan HFMD klasik. ${ }^{1}$

Hubiche dkk. ${ }^{8}$ melaporkan lesi kulit mengenai sekurangnya lima area anatomi $(>41,6 \%) .{ }^{9} \mathrm{Hal}$ ini didukung oleh studi retrospektif yang dipublikasikan oleh Yan dkk. ${ }^{13}$ pada 887 anak dengan HFMD-CVA6, menyebutkan jumlah area anatomi yang tersering terlibat adalah lima hingga tujuh area (59,4\%), diikuti dua hingga empat area (31,3\%), sedangkan yang terluas adalah sembilan area (9,3\%). Area anatomi tersebut antara lain ekstremitas bawah (56,3\%), wajah (53,1\%), batang tubuh (42,2\%), ekstremitas atas (29,7\%), dan genitalia eksterna $(58,8 \%)$. Lesi di sekitar mulut juga ditemukan lebih banyak dengan prevalensi sebesar 69,4\% dibandingkan dengan CVA16 yang hanya 17,8\%.

Penelitian yang dilakukan oleh Huang dkk. ${ }^{20}$ di Departemen Anak National Taiwan University Hospital menyebutkan bahwa lesi kulit yang disebabkan CVA6 sebanyak $90 \%$ berupa bula dan paling banyak ditemukan pada batang tubuh. Padahal Yan dkk. ${ }^{13}$ justru menyebutkan bahwa lebih banyak ditemukan papul (68,8\%) dan lesi lain berupa vesikel (64,1\%), bula (20,3\%), dan erosi $(3,1 \%)$. Vesikel kecil yang timbul pada umumnya akan berkembang menjadi vesikel yang lebih besar hingga bula. ${ }^{14}$ Gejala lain yang dapat ditemukan pada pasien adalah rasa gatal dan lebih sering dikeluhkan pada pasien dengan vesikel berukuran lebih besar dan bula (44\%) daripada pasien dengan vesikel kecil (20\%). Pada beberapa kasus ditemukan vesikel hemoragik. ${ }^{22}$ Neri dkk. ${ }^{23}$ menyebutkan bahwa pada HFMD-CVA6 dapat ditemukan vesikel berbentuk bulat dengan umbilikasi di bagian tengah, vesikulopustular, dan purpura.

Gambaran lesi kulit HFMD-CVA6 lebih berat, lebih luas, dan lebih besar dibandingkan dengan HFMD klasik. Sulit untuk membedakan infeksi akibat CVA6 atau CVA16 jika hanya berdasarkan pada gejala klinis dan gambaran lesi kulit saja. HFMD akibat EV71 juga tidak dapat dibedakan hanya berdasarkan gambaran lesi kulit.,22

Beberapa laporan kasus menyebutkan bahwa pasien HFMD-CVA6 mengalami deskuamasi dalam beberapa minggu dan perubahan pada kuku yaitu terbentuk Beau's line dan onikomadesis. ${ }^{1,2}$ Pada pengamatan setelah terapi, prevalensi onikomadesis dan deskuamasi, yaitu sebesar 36,9\% dan 50,8\%. ${ }^{19}$ Onikomadesis dapat terjadi pada minggu ke-2 hingga ke-7 dan paling banyak ditemukan pada ibu jari tangan kanan $(57,1 \%){ }^{19,22}$ Kelainan kuku seluruhnya akan membaik dan kuku akan tumbuh normal 
kembali. ${ }^{1,2}$ Deskuamasi dapat ditemukan pada minggu ke-2 sampai ke-8. ${ }^{22}$

\section{DIAGNOSIS BANDING}

Manifestasi klinis HFMD-CVA6 sangat bervariasi, dapat menyerupai penyakit lain, yaitu impetigo, ${ }^{13} \mathrm{cam}-$ pak, ${ }^{22}$ herpes simpleks, varisela, ${ }^{13}$ eczema herpeticum, ${ }^{16}$ dan jika mengenai orang dewasa dapat menyerupai sifilis sekunder. Lott dkk. ${ }^{7}$ menyebutkan bahwa diagnosis banding HFMD-CVA6 berdasarkan keterlibatan kulit. Jika hanya mengenai mukosa oral, diagnosis banding yang dapat dipikirkan antara lain herpangina, herpes simpleks, dan stomatitis. Jika lesi kulit yang terjadi cukup luas, dapat menyerupai eczema herpeticum, varisela, herpes zoster diseminata, dan eritema multiforme mayor.

Menurut Mathes dkk. ${ }^{1}$ diagnosis banding eczema coxsackium, antara lain eczema herpeticum dan infeksi sekunder bakteri pada DA. Pasien DA berisiko tinggi terjadi infeksi kulit karena kerusakan sawar dan penurunan sistem imunitas alamiah pada kulit. Manifestasi klinis yang timbul menjadi lebih luas antara lain pada infeksi virus herpes simpleks, varisela-zoster, dan smallpox. Lesi vesikulopapular generalisata yang disebabkan oleh virus herpes simpleks disebut sebagai eczema herpeticum, sedangkan Kaposi varicelliform eruption (KVE) karena varicella zoster virus dan smallpox.

Gambaran klinis pada pasien eczema herpeticum berupa erupsi vesikulopustular, erosi yang nyeri dengan predileksi di wajah, area dermatitis kronik, baik tempat predileksi DA atau bukan, batang tubuh bagian atas, dan jika mengenai mata dapat menyebabkan blefarokonjungtivitis, keratitis, dan uveitis, serta sering ditemukan limfadenopati. Sedangkan KVE merupakan faktor risiko untuk orang yang mendapatkan vaksinasi smallpox dengan virus hidup, virus yang dilemahkan, atau riwayat kontak dengan seorang pasca vaksinasi. Diagnosis dipastikan dengan pemeriksaan biakan, polymerase chain reaction (PCR), dan immunofluorescence. ${ }^{5}$

\section{PEMERIKSAAN LABORATORIUM}

Diagnosis pasti eczema coxsackium dilakukan dengan membuktikan bahwa infeksi tersebut disebabkan oleh CVA6. Beberapa cara telah dikembangkan untuk mendeteksi virus ini. Biakan virus bukan cara efektif untuk mendeteksi jenis virus, sebab banyak subtipe CVA yang tidak tumbuh pada media. ${ }^{1,15}$ Lee $\mathrm{dkk} .{ }^{5}$ menyatakan bahwa biakan hanya mendeteksi 14-16\% kasus dari yang positif dengan PCR. Spesimen untuk biakan dapat diambil dari jaringan biopsi, konjungtiva, orofaring, kulit perirektum, dan darah pada saat terjadi viremia primer.,13

Pemeriksaan lain adalah dengan real time polymerase chain reaction (RT-PCR). Pemeriksaan ini merupakan cara paling efektif untuk mendeteksi enterovi- rus, terutama CVA6. ${ }^{5}$ Feder dkk. ${ }^{2}$ menyebutkan semua pasien dengan HFMD-CVA6, terdeteksi 100\% dengan RT-PCR. Dianjurkan untuk mengambil spesimen dari cairan vesikel, ${ }^{7,15}$ apus tenggorok, perirektum, ${ }^{25}$ feses, ${ }^{2}$ darah, dan fragmen kuku yang mengalami onikomadesis. ${ }^{1}$ Spesimen dianjurkan diambil dari cairan vesikel,, 715 namun sumber lain menyebutkan bahwa spesimen lebih baik dari feses ${ }^{22}$ dan apus rektum. Fan dkk. ${ }^{4}$ melaporkan dari 508 spesimen dapat terdeteksi CVA6 sebanyak $68,9 \%$ dari feses, $67 \%$ dari apus tenggorok, dan 55,6\% dari cairan vesikel. Bahan dari darah tidak dianjurkan karena sering memberikan hasil negatif palsu. ${ }^{7}$

Ventarola dkk. ${ }^{9}$ menyebutkan bahwa selain dengan pemeriksaan PCR, CVA6 juga dapat dideteksi dengan pemeriksaan IgM. Pemeriksaan ini dapat secara spesifik mendeteksi subtipe virus coxsackie, namun belum banyak digunakan karena masih terbatas hanya untuk penelitian.

Pemeriksaan lain yang telah tersedia secara komersial untuk mendeteksi antibodi enterovirus adalah tes fiksasi komplemen. Spesimen dapat diambil dari serum pada fase akut dan konvalesen. Namun pemeriksaan ini terbatas hanya untuk 6-12 serotipe dan dapat terjadi reaksi silang dengan coxsackievirus lain, sehingga pemeriksaan tersebut tidak dianjurkan. ${ }^{7}$

Pemeriksaan histopatologik yang diperoleh dari biopsi kulit merupakan salah satu pemeriksaan yang dapat dilakukan untuk membantu menegakkan diagnosis. Hasil histopatologis kasus HFMD-CVA6 yang pernah dilaporkan oleh Mathes dkk. ${ }^{1}$ adalah spongiotic dermatitis, interface dermatitis focal dengan celah subepidermis, dan edema pada papil dermis. Selain itu, juga dapat diperoleh gambaran berupa infiltrasi limfosit perivaskular dengan sedikit degenerasi pada sel epitel superfisial. Chetrit dkk. ${ }^{14}$ menambahkan bahwa gambaran vaskulitis leukositoklastik juga dapat ditemukan pada HFMD-CVA6. Berbeda dengan yang telah dikemukakan sebelumnya, Stewart dkk. ${ }^{26}$ melaporkan bahwa gambaran histopatologis dari biopsi vesikel pada tungkai pasien HFMD-CVA6 berupa celah intraepidermis disertai dengan degenerasi retikular fokal dan nekrosis. Biopsi kulit bukan merupakan pemeriksaan yang dianjurkan karena pada HFMDCVA6 tidak menunjukkan gambaran histopatologis yang spesifik, kecuali bila ada kecurigaan terhadap penyakit lain. ${ }^{1,23}$

\section{TATALAKSANA}

Tatalaksana eczema coxsackium dan HFMD pada umumnya sama, yaitu berupa terapi suportif. Tatalaksana sesuai dengan gejala klinis yang terjadi. Bila terdapat nyeri diberikan analgetik dan bila terdapat infeksi sekunder diberikan antibiotik. ${ }^{5,13}$ Pasien dapat diberikan antibiotik topikal atau sistemik bergantung pada luas dan 
derajat infeksi yang terjadi. ${ }^{13}$ Prinsip tatalaksana eczema coxsackium adalah rehidrasi. ${ }^{7}$

American Academy of Pediatrics menganjurkan penggunaan terapi gamaglobulin intravena pada pasien imunokompromais, neonatus, dan pasien dengan gejala yang parah atau disertai infeksi sistem saraf pusat. ${ }^{13}$ Terapi lain yang pernah digunakan adalah dengan menggunakan ribavirin. Studi yang dilakukan oleh Zhang dkk. ${ }^{25}$ pada 119 anak dengan HFMD, menilai ribavirin efektif dalam mengurangi gejala penyakit. Pada penelitian ini didapatkan nilai konversi serologik menjadi negatif lebih banyak setelah terapi dengan ribavirin dibandingkan kontrol yang menggunakan plasebo.

Penelitian yang dilakukan oleh Faulkner dkk. ${ }^{28}$ menyebutkan bahwa gejala HFMD menjadi lebih baik setelah pasien mendapatkan asiklovir oral. Namun Lynch dkk. ${ }^{21}$ tidak menganjurkan pemberian asiklovir oral maupun topikal. Sebuah studi retrospektif oleh Janeczko dkk. ${ }^{29}$ menganjurkan asiklovir oral hanya untuk pasien dengan manifestasi yang berat dan dapat dipertimbangkan pemberian isoprinosin sebagai imunomodulator.

Johnson dkk. ${ }^{5}$ memperkenalkan wet wrap therapy (WWT) untuk tatalaksana eczema coxsackium. Metode ini menggabungkan penggunaan kortikosteroid topikal potensi menengah dan balutan Aquafor® yang diberikan tiga kali sehari selama tiga hari berturutan. Tatalaksana dengan cara ini menghasilkan perbaikan klinis dalam 24 jam dan respons yang sangat memuaskan setelah follow up selama lima hari tanpa efek samping.

\section{KOMPLIKASI DAN PROGNOSIS}

HFMD-CVA6 memiliki prognosis baik, meskipun demikian, penyakit ini dapat menimbulkan beberapa komplikasi. Infeksi sekunder oleh Streptococcus grup A dan Staphylococcus merupakan komplikasi yang pal-

\section{DAFTAR PUSTAKA}

1. Mathes EF, Oza V, Frieden IJ, Cordoro KM, Yagi S, Howard $\mathrm{R}$, dkk. Eczema coxsackium and unusual cutaneous findings in an enterovirus outbreak. Pediatrics. 2013;132:149-57.

2. Feder HM, Bennett N, Modlin JF. Atypical hand, foot, and mouth disease: a vesiculobullous eruption caused by coxsackievirus A6. Lancet Infect Dis. 2014;12:83-6.

3. Li W, Yi L, Su J, Lu J, Zeng H, Guan D, dkk. Seroepidemiology of human enterovirus 71 and coxsackievirus A16 among children in Guandong province, China. BMC Infect Dis. 2013;13:322.

4. Fan X, Jiang J, Liu Y, Huang X, Wang P, Liu L, dkk. Detection of human enterovirus 71 and coxsackievirus A16 in an outbreak of hand, foot, and mouth disease in Henan Province, China in 2009. Virus Genes. 2013;46:1-9.

5. Nahmias AJ, Froeschle JE, Feorino PM, McCord G. Generalized eruption in child with eczema due to coxsackievirus A16. Arch Dermatol. 1968;97:147-8.

6. Johnson VK, Hayman JL, McCarthy CA, Cardona ID. ing sering terjadi. ${ }^{13}$ Komplikasi lain adalah berupa gangguan sistem saraf pusat. Sebuah studi serial yang dilakukan oleh Lo dkk. ${ }^{28}$ di Taiwan pada tahun 2004-2009 mendapatkan 2,4\% dari 141 pasien HFMD-CVA6 mengalami meningitis maupun ensefalitis. Mathes dkk., ${ }^{1}$ serta Feder dkk. ${ }^{2}$ melaporkan beberapa pasien mengalami dehidrasi akibat ulserasi pada mukosa oral dan tidak ada pasien yang mengalami komplikasi sistemik yang serius. Komplikasi yang biasanya timbul pada infeksi CVA misalnya miokarditis, pneumonia, meningitis, dan ensefalitis. Harris dkk. ${ }^{10}$ melaporkan kejadian orkitis pada pasien dewasa dengan HFMD-CVA6.

\section{SIMPULAN}

HFMD-CVA6 merupakan spektrum penyakit HFMD yang dapat menimbulkan manifestasi kulit bervariasi dan tidak khas. Definisi eczema coxsackium hingga saat ini belum seragam di antara para klinisi. Penegakkan diagnosis secara klinis tidak mudah dilakukan dan pemeriksaan PCR belum dilakukan di semua pusat pelayanan kesehatan tersier. Walaupun penyakit ini bersifat swasirna perlu tatalaksana yang tepat pada pasien dengan eczema coxsackium guna mencegah komplikasi yang mungkin terjadi. Perlu diberitahukan kepada pasien atau orang tua mengenai perjalanan penyakit, terapi, dan gejala sisa yang dapat terjadi.

\section{UCAPAN TERIMA KASIH}

Ucapan terimakasih kepada Prof. dr. Kusmarinah Bramono, Sp.KK(K) PhD; Dr. dr. Sri Linuwih Menaldi Sp.KK(K), dr. Eliza Miranda, Sp.KK; dr. Githa Rahmayunitha, Sp.KK; dr. Rinadewi Astriningrum, Sp.KK; dan dr. Melani Marissa, Sp.KK atas asupan yang diberikan dalam penyusunan tinjauan pustaka ini.

Succsessful treatment of eczema coxsackium with wet wrap therapy and low-dose topical corticosteroid. J Allergy Clin Immunol Pract. 2014:11;803-4.

7. Horsten HH, Fisker A, Bygum A. Eczema coxsackium caused by coxsackievirus A6. Pediatric Dermatol. 2016;33:230-1.

8. Lott JP, Liu K, Landry ML, Nix WA, Oberste MS, Bolognia J, dkk. Atypical hand-foot-and-mouth disease associated with coxsackievirus A6 infection. J Am Acad Dermatol. 2013;69:732-41.

9. Hubiche T, Schuffenecker I, Boralevi F, Labreze CL, Bornebush L, Chiaverini C, dkk. Dermatological spectrum of hand, foot, and mouth disease from classical to generalized exanthema. Pediatr Infect Dis J. 2014;33:92-8.

10. Ventarola D, Bordone L, Silverberg N. Update on hand foot and mouth disease. J Clin Dermatol. 2015;33:340-6.

11. Harris PNA, Wang AD, Yin M, Lee CK, Archuleta S. Atypical hand, foot, and mouth disease: eczema coxsackium can also occur in adults. Lancet Infect Dis. 2014;14:83-6. 
12. Bian L, Wang Y, Yao X, Mao Q, Xu M, Liang Z. Coxsackievirus A6: a new emerging pathogen causing hand, foot, and mouth disease outbreaks worldwide. Expert Rev Anti Infect Ther. 2015;7:1-11.

13. Centers of Disease Control and Prevention. Notes from the field: severe hand, foot, and mouth disease associated with coxsackievirus A6-Alabama, Connecticut, California, and Nevada. November 2011-February 2012. MMWR Morb Mortal Wkly Rep. 2012;61:213-4.

14. Yan X, Zhang ZZ, Yang ZH, Zhu CM, Hu YG, Liu QB. Clinical and etiological characteristics of atypical hand-footand-mouth disease in children from Chongqing, China: a retrospective study. BioMed Research International. 2015.

15. Ben-Chetrit E, Wiener-well Y, Shulman LM, Cohen MJ, Elinav H, Sofer D, dkk. Coxsackievirus A6-related hand, foot, and mouth disease: skin manifestations in a cluster of adult patients. J Clin Virol. 2014;59:201-3.

16. Divisi Dermatologi Pediatrik RSCM - Departemen Ilmu Kesehatan Kulit dan Kelamin FKUI - RSCM. Laporan kunjungan harian 2014-2015.

17. Divisi Dermatologi Umum RSCM - Departemen Ilmu Kesehatan Kulit dan Kelamin FKUI - RSCM. Laporan kunjungan harian 2014-2015.

18. Blomqvist S, Kemola P, Kaijalainen S, Paananen A, Simonen ML, Vuorinen T, dkk. Co-circulation of coxsackieviruses A6 dan A10 in hand, foot, and mouth disease outbreak in Finland. J Clin Virol. 2010;48:49-54.

19. Muller ML. Coxsackieviruses. Available at http://www. medicine.medscape.com/article/215241-overview. Diunduh pada tanggal 29 Agustus 2016.

20. Richer M, Horwitz M. coxsackieviruses infection as an environmental factor in the etiology of type 1 diabetes. Autoimmun Rev. 2009;8:611-5.

21. Huang CW, Huang LM, Lu CY, Cheng AL, Chang LY. Atyp- ical hand-foot-mouth disease in children: a hospital-based prospective cohort study. Virol J. 2013;209:1-9.

22. Lynch MD, Sears A, Cookson H, Lew T, Laftah Z, Orrin L, dkk. Disseminated coxackievirus A6 affecting children with atopic dermatitis. Clin Exp Dermatol. 2015:40:525-8.

23. Kobayashii M, Makino T, Hanaoka N, Shimizu H, Enomoto M, Okabe N, dkk. Clinical manifestations of coxsakievirus A6 infection associated with a major outbreak of hand, foot, and mouth disease in Japan. Jpn J Infect Dis. 2013;66:260-1.

24. Neri I, Dondi A, Wollenberg A, Ricci L, Ricci G, Piccirilli G, dkk. Atypical forms of hand, foot, and mouth disease: a prospective study of 47 italian children. Pediatric Dermatol. 2016;33:429-37.

25. Lee MK, Chan PK, Ho II. Enterovirus infection among patients admitted to hospital in Hong Kong in 2010: epidemiology, clinical characteristics, and importance of molecular diagnosis. J Med Virol. 2013;85:1811-7.

26. Zhang L, Wang X, Zhang Y, Gong L, Mao H, Feng C, dkk. Rapid and sensitive identification of RNA from the emerging pathogen coxsackievirus A6. Virol J. 2012;9:298.

27. Stewart CL, Chu EY, Introcaso CE, Schaffer A, James WD. Coxsackievirus A6-induced hand-foot-mouth disease. JAMA Dermatol. 2016;149:1419-21.

28. Faulkner CF, Godbolt AM, DeAmbrosis T, Triscott J. Hand, foot, and mouth disease in an immunocompromised adult treated with acyclovir. Australs J Dermatol. 2003;44:203-6.

29. Janeczko J, Baranowska M, Romawska B. Effect of isoprinosine and acyclovir on the clinical course of chickenpox and herpes zoster. Przeql Epidemiol 1991;45:267-71.

30. Lo SH, Huang YC, Huang CG, Tsao KC, Li WC, Hsieh YC, dkk. Clinical and epidemiologic features of coxsackievirus A6 infection in children in northern Taiwan between 2004 and 2009. J Microbiol Immunol Infect. 2011;44:252-7. 